\title{
15 The Quran: A LEGAL SYSTEM OR A PATH FOR FLOURISHING?
}

\section{T. Jeremy Gunn ${ }^{1}$}

\section{INTRODUCTION}

Since the 1930s, Islamists increasingly have invoked the term "sharia" to identify the law that guides human beings to paradise. They use "sharia" sometimes to signify "God's law" in its perfection, but at other times to suggest the totality of the rules and laws that should be enforced by modern states. Alternatively, sharia is derided by many who are hostile to Islam for its supposedly being "violent", "reactionary", "primitive" or "harsh". This alternative version of sharia does not allow people to flourish, but instead stifles human freedoms and suffocates women who seek to thrive in the modern world. Many opponents in this polemical debate nevertheless share the assumption that sharia signifies, for better or worse, a complex series of laws and injunctions to control a broad spectrum of human behaviour, including determining what people are permitted to drink, eat, wear, and believe, as well as how they should be punished for violating the law and with whom they are allowed to marry and have sexual relations. This debate about the meanings of "sharia" arises not only in the Middle East, the Maghreb, Pakistan, Indonesia, and Malaysia, but in Africa as well. ${ }^{2}$

But what does "sharia" actually mean? Although this chapter does not purport to explain the diverse ways in which sharia has been employed in Islamic history, it does suggest that the original Quranic usage - where it means "path" and particularly "a path to water" - is self-evidently a guiding metaphor about the way people should live that bears connotations entirely different from a system of laws, rules, commands, duties, and obligations. Indeed, the Quran eschews the Arabic word for "law" as in a legal system - kanun - in favour of the metaphor of "path", which is repeatedly invoked in the Quran, with its Arabic synonyms of sirat, sabil, tarik and minhaj. Thus, it may be suggested that the Quran is better understood not as a providing a complex, lengthy or complete book of rules to be codified by legislators and enforced by judges, but as offering a metaphorical path to guide and inspire human behaviour. We are not presented with the letter of the law, but a path to paradise.

1 Professor of Law and Political Science, International University of Rabat.

2 For Africa, see for example, Chesworth J and Kogelmann F (eds). 2014. Sharí'a in Africa Today: Reactions and Responses. Leiden: Brill (see also a positive review noting that the book nevertheless did not adequately discuss the meanings of "sharia", Bolton C. 2015. Islamic Africa 6:220-223); Otto JM (ed). 2010. Sharia Incorporated: A Comparative Overview of the Legal Systems of Twelve Muslim Countries in Past and Present. Leiden: Leiden University Press, chs 5 (Sudan), 12 (Mali), 13 (Nigeria); Kendhammer B. 2013. "The Sharia Controversy in Northern Nigeria and the Politics of Islamic Law in New and Uncertain Democracies", Comparative Politics 45:291-311; Bolaji MHA. 2010.“Shari'ah in Northern Nigeria in the Light of Asymmetrical Federalism", Publius 40:114-135. 


\section{MODERN REFERENCES TO USES OF SHARIA AS STATE LAW}

The word "sharia" has become a salient, provocative and controversial term that raises questions about the interrelated roles of religion, law, politics and governance. Throughout the Muslim world, from Africa, to the Middle East, to Indonesia, there are individuals, groups and even states that insist that sharia should be fully incorporated into state law. Some Muslim-majority states insert the term "sharia" in their constitutions, statutes, and judicial rulings. Several states that ratified the Convention on the Elimination of All Forms of Discrimination Against Women (CEDAW) and the Convention on the Rights of the Child (CRC) issued reservations to those conventions stating that the human rights treaties would not be implemented to the extent that they conflict with sharia. Some violent groups, such as the Islamic State (ISIS or Daesh) have proclaimed the necessity of instituting a Caliphate whose laws are based upon sharia. Elsewhere, in the non-Muslim world, the term "sharia" is increasingly invoked as the spectre of an encroaching Islam that is characterised as being a violent religion. Examples of groups committing acts of terror in the name of Islam are cited in support of such characterisations. Sharia is thus cited both by some Muslims and by anti-Muslims as authorising violent punishments, including beheadings, stoning to death, and limb amputations, as well as for promoting controversial practices regarding polygamy, child marriage, and discrimination against women.

In response to such invocations of sharia both by those who are favourable or hostile to Islam, some polities in the non-Muslim world have begun proposing laws prohibiting the introduction of sharia into their states and communities, as if sharia were an imminent legal threat. For example, according to the Haas Institute at the University of California Berkeley, dozens of anti-sharia bills have been introduced in state legislatures in the United States, assisted by the publication of a state model act entitled "American Laws for American Courts". ${ }^{3}$ According to the Southern Poverty Law Center, which tracks racist movements in the United States, anti-sharia legislation has been introduced in legislatures in more than 40 states, and 14 bills have been enacted into law. ${ }^{4}$ But what actually is this "sharia" that has become a lightning rod in recent controversies involving Islam?

\section{"SHARIA" OR “ISLAMIC LAW"?}

Today the term "sharia" is widely, though not universally, understood to be roughly synonymous with the term "Islamic law". Joseph Schacht, an important scholar whose views on some aspects of Islamic law are often contested, offers a conventional

3 Elsheikh E, Sisemore B and Lee NR. 2017. "Legalizing Othering: The United States of Islamophobia", Haas Institute Research Report. Berkeley, CA: Haas Institute for a Fair and Inclusive Society, University of California, September, 21-24. Online at: https://haasinstitute.berkeley.edu/global-justice/islamophobia/legalizing-othering. See Elliott A. 2011. "The Man Behind the Anti-Shariah Movement", New York Times, 30 July. 
definition of "sharia" as the "sacred Law of Islam" and as "an all-embracing body of religious duties, the totality of Allah's commands that regulate the life of every Muslim in all its aspects; it comprises on an equal footing ordinances regarding worship and ritual, as well as political and (in the narrow sense) legal rules". ${ }^{5}$ Wael Hallaq, throughout his highly regarded Sharia: Theory, Practice, Transformations, as well as his Introduction to Islamic Law (a shortened version of Sharia) largely treats "Islamic law" and "sharia" as synonymous and interchangeable terms, sometimes referring to one and sometimes to the other. Mohammad Hashim Kamali distinguishes between the differences in meaning of "sharia" in the Quran, which I will discuss further below, and sharia as an encompassing religious-world view, and a sharia that emphasises what might be seen as legal norms and rules. ${ }^{6}$ Yet he also largely uses "Islamic law" and "sharia" as interchangeable terms. One of the most prominent Muslim interpreters of the relationship between Islam and the state - Sheikh Yusuf Al-Qaradawi - understands "sharia" in Arabic to be the same thing as "Islamic law" in English. ${ }^{7}$ Al-Qaradawi, an Egyptian who formerly was a member of the Muslim Brotherhood, is widely revered by many Muslims and was arguably the most famous Muslim scholar in the world during the first two decades of the twenty-first century. Although not universally accepted, either within Islam or by Islamic scholars, it is very common today to treat the terms "sharia" and "Islamic law" interchangeably and as an expression of the totality of the laws, norms and values in Islam that have emerged from the prophetic revelations of Mohammed the Messenger and the subsequent developments following the revelation of the Quran. Muslims will disagree amongst themselves about the extent to which the sharia should be understood in strictly legalistic terms and the extent to which Islam is much more than any sum total of laws. ${ }^{8}$

Until relatively recently, a difference was often maintained between sharia as perfect, divine law known in its totality only by God, on the one hand, and figh, which is the human understanding of divine law, on the other. ${ }^{9}$ According to this differentiation, sharia was immutable, unchanging, perfect, but ultimately knowable in its entirety only to God, while figh was the necessarily fallible attempt by human beings to understand the perfect divine law. (The jurisprudential effort to understand divine law is known as usul al-figh.) While figh might change over time amongst peoples and generations, sharia could never change. Although this classic distinction between divine sharia and human understanding as figh continues to be recognised, it is largely absent from modern political debates about the introduction

5 Schacht J. 1982. An Introduction to Islamic Law. Oxford: Oxford University Press, 1.

6 Kamali MH. 2008. Shari'ah Law: An Introduction. Oxford: Oneworld Publications.

7 See his State in Islam in its official English translation, Al-Qaradawi Y. 2004. State in Islam. Third Edition. Al-Falah Foundation (transl.). Cairo: Al-Falah Foundation, 17, 75 and passim (using the English and Arabic terms interchangeably).

8 Many Sufis, though not all, will understand the legal aspects of sharia as a framework or structure of Islam, although not its heart or essence.

9 A helpful elaboration of the following points may be found in Abou El Fadl K. 2013. "The Shari'ah", in Esposito JL and Shahin EE (eds). The Oxford Handbook of Islam and Politics. Oxford: Oxford University Press, 12-15. 
of sharia into the laws of the states. Muslim activists and Islamists do not issue calls for the introduction of laws based on figh (which would make perfect sense), but for the introduction of sharia (which does not make sense according to the traditional vocabulary and categories). Al-Qaradawi, for example, continues to use the word "usul al-figh" to describe jurisprudential reasoning, but does not differentiate clearly between "figh" and "sharia" when describing the laws under which Muslim states should operate. ${ }^{10}$ As the term "sharia" is increasingly deployed in rhetoric regarding religion and politics, the use of the more appropriate term "figh" is in decline. There are no rallying cries to introduce figh into state laws or to invoke figh as a reservation in a human rights convention as a basis for not otherwise complying with the treaty, as has been done with sharia.

\section{SHARIA AS PART OF A LARGER DEBATE ABOUT THE RELATIONSHIP BETWEEN ISLAM AND THE STATE}

The polemic about sharia within the larger debate within the Muslim world about the proper relationship between Islam and the modern state is only one of the contested elements, even if it is the most salient. Of the many different debates about the preferred relationship between religion and the state, it may be useful to consider two opposing approaches taken by important Muslim scholars. One widely accepted view today is associated with the prominent media personality mentioned above, Sheikh Yusuf Al-Qaradawi. Although his book, State in Islam, is not his bestknown publication, it articulates the view that Islam is a "comprehensive" system that encompasses religious obligations, identity, and a way of life, and that sharia should form the basis of law of Muslim-majority states. ${ }^{11}$ Al-Qaradawi insists that in Islam, unlike Christianity, there can be no separation between religion and the state. and that the introduction of this concept in the Muslim world came from Western imperialists. ${ }^{12}$ Similarly, secularism in any part of human activity should be understood as being anathema to Islam. ${ }^{13}$

A quite different and much less recognised approach is that of Ali Abdel Razek, who argued in a famous 1925 publication that Islam is a religion and not a state. ${ }^{14}$ For Abdel Razek, the state is a modern, Western invention that has little to do with the original teachings of Islam or practices that were followed during the Prophet's life in seventh-century Medina. The Prophet Mohammed and the Quran

10 Al-Qaradawi, State in Islam, 109-120.

11 Al-Qaradawi, State in Islam, 25-26, 29, 123-125.

12 Al-Qaradawi, State in Islam, 3, 17, 25, 37, 124.

13 Al-Qaradawi, State in Islam, 4, 11, 37, 80-81, 105-106, 140.

14 Abdel Razek A and Filali-Ansary A. 2013. Islam and the Foundations of Political Power. Loutfi $\mathrm{M}$ and Esmail A (transl.). Edinburgh: Edinburgh University Press. For a study of Abdel Razek, see Ali ST. 2009. A Religion, Not a State: Ali Abd Al-Raziq's Islamic Justification of Political Secularism. Salt Lake City: University of Utah Press. Al-Qaradawi makes brief but negative references to Abdel Razek in State in Islam, 9-11, 101. 
conveyed divine commandments for human beings to follow and did not establish a framework for governing a state, particularly the modern state, which is largely a Western novelty that came to fruition 1,000 years after the Prophet's death. For Abdel Razek, Muslims have a religious obligation to comply with divine commands of Islam and the modern state is not well-situated as an instrument for the enforcement of those commands. Thus, for Al-Qaradawi, the state should be Islamic and state laws should enforce divine commands. For Abdel Razek, the state has a corrupting role when it mixes itself with religion.

\section{THE QURAN AND THE SOURCES OF ISLAMIC LAW}

In Sunni Islam today, Islamic law (whether under the name of sharia or not) is understood as having four sources: the Quran, the sunnah, qiyas, and ijma. The Quran is, of course, the word of God as revealed through the angel Gabriel to the Prophet Mohammed and subsequently recorded by his companions. The text is understood to be the infallible word of God and is the fundamental basis for all Islamic law. While the Quran is understood to provide authoritative and dispositive law, it nevertheless contains relatively few texts that may be described as "legal". Of the more than 6,200 verses (ayat) in the Quran, only a small percentage focuses on what may be described as legal or legislative matters. According to Wael Hallaq, one of the most prolific living scholars of Islamic law: "Medieval Muslim jurists and modern scholars seem to agree that the Qur'an contains some five hundred verses with explicitly legal content."15 Kamali identifies a lesser number, approximating $350 .{ }^{16}$ Even if we take the higher estimate, this means that only slightly more than twelve percent of the number of Quranic verses are legal in nature. The vast majority cover non-legal issues such as the characteristics of God, the wonders of the earth, the nature of paradise, and the histories and biographies of earlier peoples. However important the Quran is for laying the foundation of Islamic law, the text itself is preponderantly not legal in nature.

The sunnah, the second source of Islamic law, consists of scholars' interpretations of the words and example of the Prophet derived from hadith, narrations of the Prophet's words and example that had been transmitted (isnad) orally until written and compiled 150-200 years after his death. There are debates about the reliability and interpretation of different hadiths, but their meanings may never contradict the Quran. Qiyas, typically translated as "analogy", is a form of reasoning based upon applying principles that are understood from the Quran and sunnah to situations that are not expressly covered in the Quran and sunnah. ${ }^{17}$ The fourth generally accepted source of Sunni Islamic law is the "consensus" of the Muslim scholarly

15 Hallaq W. 2001. "Law and the Qur'an", in McAuliffe JD. 2001. Encyclopaedia of the Qur'an. Leiden: Brill, 150.

16 Kamali, Shari'ah Law, 3.

17 The Quran, for example, criticises the misuse of wine. By analogy, the same criticism and ultimate condemnation could be made against hard liquor, which is not mentioned in the Quran. 
community about the law. It is argued that the Muslim community (ummah), as a whole, cannot misinterpret the law, and thus past and current understandings constitute an important source of law.

Although the text of the Quran itself is set and unchanging, the sunnah, qiyas and ijma may change over time. Importantly, this Islamic law, or sharia, other than the portion consisting of the Quran itself, is not a written text. This simple fact reveals that there is a fundamental difference between the written legislation of the modern nation-state, which can be embodied in statutes and written texts, versus Islamic law, which necessarily is subject to ongoing interpretations. ${ }^{18}$ The sharia includes written texts, most notably the Quran and the hadith, but it also includes a reasoning process. Part of the reasoning process is followed through questions posed to religious scholars (ulama), are answered in the form of non-binding legal opinions (fatwas).

In short, the term "sharia" is now widely understood to be synonymous with the entire body of Islamic law and to cover the entire scope of "laws", "commandments", "obligations", "prohibitions" and "recommendations". ${ }^{19}$ However, like the unwritten English Constitution, one cannot go into a library and ask to be shown a written document that comprises the entire English Constitution or the sharia. Although neither codified nor fully written, and thus differing from the typical legal system of a modern state, sharia is nevertheless understood to be a rigorous, complex and intricate system of law that articulates duties, responsibilities and some rights.

\section{WHAT DOES THE QURAN SAY ABOUT "SHARIA"?}

In order to understand further the meaning of the term "sharia", it should be of interest to understand how the term is used in the Quran, which is the principal, fundamental, and infallible source of Islamic law. Specifically, does the Quran itself employ the term "sharia" to signify a comprehensive system of law to be employed either by a state or by any political body? Do Islamists arguing for the implementation of sharia have a Quranic basis for their assertion?

The noun "sharia", which plays a salient role in contemporary debates, appears only once in the Quran. ${ }^{20}$ The following are four noted English translations of this

18 A closer analogy might be drawn between Islamic law and the law of a common-law state (such as the United Kingdom or the United States), where judge-made law is an important part of the law but cannot be conveyed precisely in codes or statutory compilations. Although this is indeed a closer analogy, it should be noted that, apart from the Quran, no "Islamic law" statutes can be precisely written, with the arguable exception of certain laws pertaining to inheritance.

19 The extent to which the modern state should play a role in enforcing or applying sharia is an important and controversial question that will not be discussed here.

20 Sheikh Al-Qaradawi acknowledges that the nominative form of the word occurs only once in the Quran, but he says that this has no significance because other words of great importance, including "morality", "virtue", and "faith", are used only once or not at all in the Quran and sunnah. Al-Qaradawi, State in Islam, 166. Al-Qaradawi offers no explanation 
important Quranic verse found at sura 45 aya 18. The royal "We" in the translations below refers to God (Allah) and "thee" refers to the Prophet Mohammed, who received the revelation.

Then We placed thee upon a clear path (shariat al-minal) from the Command; so follow it, and follow not the caprices of those who know not. (Nasr) ${ }^{21}$

Then we put thee on the (right) Way of religion; so follow thou that (Way) and follow not the desires of those who know not. (Ali) ${ }^{22}$

Then We have established you on the correct path; so follow it and do not follow the desires of those who do not know. (Yüksel) $)^{23}$

Then We set thee upon an open way of the Command; therefore follow it, and follow not the caprices of those who do not know. (Arberry) $)^{24}$

Therefore, the only time that sharia is employed in the Quran as a noun is in one single verse, where God gives instructions to only one person, His chosen Messenger, and not to all Muslims nor to all of humanity. "Sharia" (or plural "shariat"), as we see from the translations above, is alternatively understood in English as meaning "path" or "way", with the qualifying adjective being alternatively translated as "open", "clear" or "correct". It should be noted that the verse does not conjure legalistic notions such as "laws", "rules" or "regulations", but invokes instead the metaphor of a path to be followed.

As noted above, the second recognised source of Islamic law in Sunni Islam is the Sunnah, which is based upon the hadith. Curiously, the term "sharia" also appears only rarely amongst the thousands of hadith that were compiled during the two hundred years following the death of the Prophet. According to one authoritative source:

In the corpus of hadith ... shari'a occurs once in the singular, in a hadith in the Musnad of Ibn Hanbal: "the community shall remain on the shari'a (path/way)." [The] plural form occurs not more than a dozen times, mostly in locutions like [in the paths of Islam or in the paths of belief.] The [root]

of why this particular word came to have such significance, something that would not be difficult to explain with regard to the other three words that he offers as examples.

21 Nasr SN. 2015. The Study Quran: A New Translation and Commentary. New York: HarperOne. This recent translation is highly regarded. The team that prepared the translation and commentary are well-established Muslim scholars.

22 Ali AY. 2001. The Holy Quran: Text, Transliteration, Translation \& Commentary. New Delhi: Kitab Bhavan. The Ali version helpfully includes the Arabic original, an English translation, and a transliteration. Ali died in 1953. Several reissues of his original translation are available through different publishers worldwide.

23 Yüksel E, Al-Shaiban LS and Schulte-Nafeh M. 2007. Quran: A Reformist Translation. Brainbow Press, n.p. Some controversy surrounded the release of the Yüksel translation, as the original publisher withdrew after receiving protests. Some would describe the Yüksel version as a "reformist" interpretation of the Quran.

24 Arberry AJ. 1955. The Koran Interpreted. New York: Macmillan. The Arberry translation is often recommended for academic readers. 
word shar' does not occur with the connotation of religion or law, and the verbal form shara' $a$ occurs only once with these connotations, in a set of variations of the same hadith: "God has laid down for his [var. your] Prophet the rules of guidance." 25

In conclusion, the word that is often invoked today to identify all Islamic law, and that has become subject to polemical arguments both inside and outside the Muslim world, occurs only once in the Quran and a dozen times in all of the other original written sources and always refers to a path or way and never to a comprehensive legal system.

\section{SHARIA: A PATH TO WATER AND HUMAN FLOURISHING}

Although not specifically invoked within the text of Quran 45:18, scholars note that "sharia" in Arabic at the time of the Quran typically bore the connotation of being not simply a path, but a path leading to water. An important commentary offers the following explanation of the verse:

In this context, clear path translates sharì'ah, which later became the technical term for Islamic Law, though it occurs only this one time in the Quran. Linguistically, sharī'ah means a straight, smooth path that leads to water, which in the deserts of Arabia would also have meant a path to salvation from death. In this context it thus appears to indicate a clear path by which God leads people to the truth. ${ }^{26}$

The connotation of sharia as being a path to water was part of a broader understanding of the meaning of the word.

The lexicographical tradition recognises two major (and a number of minor) areas of use [of sharia] which are without religious connotation. In a corpus of poetry and of hadith evoking a pastoral and Bedouin environment, the verb shara' $a$ and its derivatives relate to watering animals at a permanent water-hole. The verb implies lapping at, or drinking, water, and has animals as its subject. Shari'a designates the area round a water-hole, or the point of entry to it, the place at which the animals drink, a place and not a road. Shara'a, sharra'a, possibly ashra'a, all mean to drive (or lead) animals to water. Adjectival usage indicates animals en route to or lapping at water. Shari'a also signifies the seashore, again with special reference to animals which come there. ${ }^{27}$

25 Calder N. 1997. "Shari'a”, in Bosworth CE, Van Donzel E, Heinrichs WP and Lecomte G (eds). The Encyclopaedia of Islam, vol. 19. Second Edition. Leiden: Brill, 321.

letter root term (sh-r-') as including "to come to water to drink, paths leading to drinking spots, to drink with the hand ...". Badawi EM and Abdel Haleem MA. 2008. Arabic-English Dictionary of Qur'anic Usage. Leiden: Brill, 481. It should be noted that they also suggest that this may be a root for legislation from God. This follows from Calder's suggestion that human beings' driving animals to water becomes a trope for God's directing people to the true religion. 
The connotations that sharia evokes are of paths leading to water rather than laws, rules, or regulations to which human beings are required to comply, but as a way to find life-giving water necessary for human survival in the deserts of Arabia. But water is more than a mere necessity of life. Water in the Quran refers not only to an element that makes possible human flourishing on earth, for it is the repeated descriptor for paradise, which is abundant in never-ending streams.

The Quran holds that God "made every living thing from water". ${ }^{28}$ Not only was everything created out of water, but water is necessary for God's creation to survive. It is a gift from God that brings life to all forms of vegetation. "And We sent down blessed water from the sky whereby We grew gardens and the harvested grain." 29 The well-watered garden is a symbol of life and peace. Water comes not only in the form of rain, but also from springs that nourish plants, for which people should be grateful. "And We place gardens of date palms and grapevines therein and make springs flow forth, that they may eat of its fruit and of that which their hands have worked. Will they not then give thanks?"30 Paradise, destined for those who live righteously, is replete with rivers running below the surface. ${ }^{31}$ Paradise will have gushing springs ${ }^{32}$ and splendid fountains. ${ }^{33}$ Sharia as a path leading to water inherently evokes images of streams and springs rather than legal codes and statutes.

Sharia is not the only term used in the Quran to refer to paths. There are several other words in the Quran that are largely synonymous with each other - sirat, sabil, tarik, and minhaj - all of which may be translated into English as "path", "way", "route", or "road". Of these, probably the most commonly invoked term is sirat, including when it is qualified as "al-sirat al-mustaqim": the straight path.

Sirat (path) and al-sirat al-mustagim (straight path):

Guide us on the straight path. (Q1:6)

The fools among the people will say, "What has turned them away from the qiblah they had been following?" Say, "To God belong the East and the West. He guides whomsoever He will unto a straight path." (Q2:142)

And God guides whomsoever He will unto a straight path. (Q2:213)

As for those who believe in God and hold fast to Him, He will cause them to enter into His Mercy and Bounty, and will guide them unto Himself upon a straight path. (Q4:175)

Truly God is my Lord and your Lord; so worship Him. This is a straight path. (Q3:51)

Q21:30; see also Q24:45; Q25:54. All subsequent quotations from the Quran are taken from the Nasr, Study Quran.

Q50:9; see also Q23:18, Q27:60, Q31:10, Q35:27, Q39:21. 
O People of the Book! Our Messenger has come unto you, making clear to you much of what you once hid of the Book, and pardoning much. There has come unto you, from God, a light and a clear Book, whereby God guides whosoever seeks His Contentment unto the ways of peace, and brings them out of darkness into light, by His Leave, and guides them unto a straight path. (Q5:15-16)

Those who deny Our signs are deaf and dumb, in darkness. Whomsoever God will, He leads astray, and whomsoever He will, He places him upon a straight path. (Q6:39)

And God calls unto the Abode of Peace, and guides whomsoever He will unto a straight path. (Q10:25)

[And he was] thankful for His Blessings. He chose him and guided him unto a straight path. (Q:16:121) (referring to Abraham)

And so that those who have been given knowledge might know that it is the truth from thy Lord, and thus believe in it, and that their hearts be humbled before Him. And truly God guides those who believe unto a straight path. (Q22:54)

Thus have We revealed unto thee a Spirit from Our Command. Thou knewest not what scripture was, nor faith. But We made it a light whereby We guide whomsoever We will among Our servants. Truly thou dost guide unto a straight path. (Q42:52-53)

So hold fast to that which We have revealed unto thee. Truly thou art upon a straight path. (Q43:43)

Other Arabic terms similarly are translated into English as "way" or "path":

Tariq:

Verily those who disbelieve and do wrong, God will not forgive them, nor will He guide them to any path, save the path of Hell, to abide therein forever; and that is easy for God. (Q4:168-169)

And indeed We created above you seven paths ... (Q23:17)

Some among us are righteous, and some among us are otherwise; we are on paths divided. (Q72:11)

Sabil:

Those who turn from the way of God and seek to make it crooked. (Q7:45)

... those who turn from the way of God and seek to make it crooked (Q11:19)

Follow our path and we shall bear your sins. (Q29:12)

Then when He bestows a blessing from Himself upon him, he forgets the One upon whom he called before and sets up equals unto God to lead astray from His path. (Q39:8) 
Minhaj:

We have appointed a law and a way. $(\mathrm{Q} 5: 48)^{34}$

Two important conclusions that may tentatively be drawn from these examples. First, "sharia" is but one of several synonymous terms that are employed throughout the Quran to describe the path that people should follow, and it is a term that is employed less frequently than some of the alternatives. Second, all of the terms bear the immediate connotation of "path" or "way" and not "law" or "rules". God's instructions for humans, in these passages, are conveyed not as a series of laws, commandments, or rules to be obeyed strictly or to the letter, but as general guidance along a metaphorical path. The Quran speaks to humans, at least in these passages, not as subjects of rigorous legal code, but as people who are offered realworld imagery to help them understand: paths, water, trees, animals, lightness and darkness, heat, and thirst. For humans, the Quran of these passages offers a path to water and salvation rather than strict code to which rigorous compliance is demanded.

\section{PATHS IN RELIGIOUS TEXTS OUTSIDE ISLAM}

\section{"Path" in Daoism}

The invocation of terms such as "path" or "way", in contrast to more legalistic terms such as "law" or "regulation", are invoked in several religions to signify how people should orient themselves in order to attain enlightenment, salvation or live in harmony with nature. ${ }^{35}$ Perhaps the most obvious such example is Daoism (alternatively Taoism), where the identifying word "dao" itself means "path" or "way". ${ }^{36}$ The fundamental text of Daoism, the Dao Te Ching (or Tao De Jing), "is the

34 The Arabic word that is translated here as "law" is shir'atun. This word has the same Arabic root as sharia: path. See Badawi and Haleem, Arabic-English Dictionary, 481.

The term "dharma" (roughly meaning "to hold") plays something of an analogous role in Hindu literature: "Dharma is undoubtedly the most central and ubiquitous concept in the whole of Indian civilization. ... This very centrality, however, also made it possible for the concept to be given new twists and meanings at different times and by different groups, creating a dauntingly broad semantic range. ... It is also a challenging term to translate or even to define adequately." Olivelle P. 1999. Dharmasutras: The Law Codes of Apastamba, Gautama, Baudhayana, and Vasistha. Oxford: Oxford University Press, xxxvii. While the root of dharma signifies "to hold" or "to support", its connotations later expanded over time to encompass such diverse concepts as correct ritual procedure, pious attitudes and actions, right behaviour of Brahmins, the correct order, guidelines for productive living, prohibition of criminal acts, personal hygiene, sexual conduct, etiquette, punishments for infractions, and ultimately law. Olivelle, Dharmasutras, xxxviii-xxxix. See also Bowles A. 2007. Dharma, Disorder, and the Political in Ancient India: The Apaddharmaparvan of the Mahabharata. Leiden: Brill, 81-86.

36 For transliteration differences between Wade-Giles (tao) and Pinyin (dao), see Hu HL and Allen WC. 2005. Taoism. Philadelphia: Chelsea House, 5. 
most important canon of Daoist philosophy, as well as the most important scripture of the Daoist religion". ${ }^{37}$ According to Stephen Bokenkamp, a leading scholar of Daoism,

The defining concept of the Daoist religion is the Dao itself, understood in a particular way. The term dao, originally denoting a "way" or "path", came to be used in pre-Han philosophical discourse to refer to the proper course of human conduct and, by extension, to the teachings of any philosophical school, especially insofar as these were based on the venerated ways of the sages of antiquity. In the Laozi, the Zhuangzi, and other early writings, the Dao came to be seen not as human order, but as the metaphysical basis of natural order itself, inchoate yet capable of being comprehended by the sage, primordial yet eternally present. ${ }^{38}$

Hsiao-Lan $\mathrm{Hu}$ and William Cully Allen similarly characterise dao as meaning "the way, the road people walk on. More abstract meanings derived from this basic meaning include direction, rule, ideal, and the operating principle of the universe" ${ }^{\prime \prime}{ }^{39}$ This operating principle is not handed down by an all-knowing God, but rather is "understood to be circularity and balance; therefore, human beings need to attune themselves with Tao in the same manner. [There] is a correspondence between the universe on the one hand, and human physiology and social life on the other". ${ }^{40}$ These principles "originate from nature, so they should be modeled after their origin". "To be one with Tao" therefore means to make one's life correspond to the way things are in the universe". ${ }^{41}$

While Daoism and the Quran both deploy the trope of the "path" to illuminate the proper course of conduct for human beings, in Daoism there is no all-knowing God who directs people to follow the true and straight path and who promises rewards in paradise for those who follow the path or punishments in hell if they do not. The dao is a principle that emerges from nature itself and adheres to natural processes. People should follow the dao because it brings them into harmony with the cosmos in this life and not because they are ordered to do so by God. ${ }^{42}$

37 Tang Y. 2015. Confucianism, Buddhism, Daoism, Christianity and Chinese Culture. Berlin: Springer, 157. It is perhaps useful to distinguish the Daoist religion, which is understood to have emerged in the first century of the common era, contemporaneously with the arrival of Buddhism in China, and the ancient origins of the Daoist worldview, particularly as presented in the text Tao Te Ching, ascribed to Lao Tse, which arose perhaps five-hundred years before the religion. For difficulties with dating, see Tang, Confucianism, 153-154, 157, $163,168,173-175$.

38 Bokenkamp SR. 2005. "Daoism”, in Jones L (ed). Encyclopedia of Religion, 15 vols. Second Edition. Detroit: Macmillan Reference USA, 2177.

$\mathrm{Hu}$ and Allen, Taoism, 3.

$40 \mathrm{Hu}$ and Allen, Taoism, 26.

$41 \mathrm{Hu}$ and Allen, Taoism, 26.

42 Even Daoism, which originates far from a rules-based system, later developed its own "legalistic" tendencies from Mohism and elsewhere, thus perhaps acting as something of a precursor for what may have been a similar move in Islam. See Kirkland R. 2004. Taoism: The Enduring Tradition. New York: Routledge, 27-29. There is very little in the way 


\section{Paths in Buddhism}

The same trope of "path" appears in other eastern religions and philosophies, including Confucianism and Buddhism. ${ }^{43}$ Indeed, the concept of "path" or "way" is "central to Buddhist thought". ${ }^{44}$ According to Sangharakshita, both a prolific scholar and a practising Theravadan Buddhist monk, "However little we may know about Buddhism we will at least know that it is a Path or Way. It is a Path or Way leading to a state of realisation of Truth, or of oneness with Reality, which we call Enlightenment, or Nirvana, or the realisation of one's own innate Buddhahood." 45 The Encyclopedia of Buddhism finds that it is "practically inconceivable to try to understand the Buddhist doctrinal outlook and programmes of practice without appreciating and making reference to their conception of the path" ${ }^{46}$ The concept of the path "is without a doubt one of the most important Buddhist concepts, and beyond Buddhism, of many Asian traditions. [The] idea of the path encompasses the whole of Buddhist teaching and practice" ${ }^{\prime 4}$

Of the many occurrences of the terms "path" and "way" in Buddhist writings, the two most prominent are in conjunction with the concepts of the Middle Way ("way" is "patipada" in Pali and "middle way" is "majjhima-patipada") and of the Eightfold Path ("path" is "mārga" in Sanskrit and "magga" in Pali, and "eightfold path" is "atthangika-magga"). "Magga" means a "road, way, or footpath". ${ }^{48}$ It refers to the "the road of moral [and] good living; the path of righteousness" with reference to the "the moral standard". The dictionary explains that the term is frequently raised in Buddhist writings and that it "forms the cornerstone of the Buddha's teaching". ${ }^{9}$ The term "patipada", according to the dictionary, refers to the "path, way, means, method, mode of progress" and "line of conduct". The latter, patipada is described by the dictionary as being a "quasi synonym of magga". ${ }^{50}$

of the practice of Chinese religions in Africa. For a discussion of an exception, see Song A. 1982. "Chinese Religion: The Chinese Community in Southern Africa", Religion in Southern Africa 3(1):19-30.

43 For the difficulty of the term "dao" and the Confucian deployment of it, see particularly Hansen C. 1992. A Daoist Theory of Chinese Thought: A Philosophical Interpretation. New York: Oxford University Press, 83-84.

Gethin RM. 2001. The Buddhist Path to Awakening: A Study of the Bodhi-Pakkhiyā Dhamma. Oxford: Oneworld Publications, 18. See also Buswell RE and Gimello RM. 1992. Paths to Liberation: The Mārga and Its Transformations in Buddhist Thought. Honolulu: University of Hawaii Press, 23 ("the centrality of mārga to Buddhism").

Sangharakshita. 1999 Vision and Transformation: An Introduction to the Buddha's Noble Eightfold Path. Second Edition. Birmingham: Windhorse, 9.

Chu W. 2004. "Path", in Buswell RE (ed). Encyclopedia of Buddhism, 2 vols. New York: Macmillan Reference, 639.

Harter P-J. 2017. "Mārga (Path)”, in Oxford Bibliographies. Oxford: Oxford University Press.

Rhys Davids TW and Stede W. 1921. The Pali Text Society's Pali-English Dictionary. Chipstead, UK: Pali Text Society, 312. 
Both the terms "Middle Way" and the "Eightfold Path" appeared originally in the Buddha's first sermon (in the Deer Park at Sarnath) that he delivered after attaining enlightenment and in which he explains the core of his message. ${ }^{51}$ The Middle Way is the "nucleus of the Buddha's teaching" and the Eightfold Path is the explanation of the way to overcome suffering and attain enlightenment. ${ }^{52}$ The Buddha describes his Middle Way as one lying between extreme asceticism, which he had practised earlier, and a life of indulgence (which was associated with his youth). The Deer Park sermon identifies the Four Noble Truths (the first three of which pertain to suffering and overcoming suffering). The Fourth Noble Truth is the Eightfold Path (magga) that explains the way to be followed to attain enlightenment and Buddhahood. According to Bhikkhu Bodhi, one of the pre-eminent English-speaking scholars of Theravada Buddhism, the "Eightfold Path stands at the very heart of the Buddha's teaching. It was the discovery of the path that gave the Buddha's own enlightenment a universal significance and elevated him from the status of a wise and benevolent sage to that of a world teacher" ${ }^{53}$

The concept of the path is pervasive in explanations of Buddhism. ${ }^{54}$ The classic summary of Theravada Buddhism, whose very title emphasises the term "path", Bhadantacariya Buddhaghosa's classic fifth-century work, The Path of Purification, ${ }^{55}$ has been described by the Dalai Lama as the "epitome of Buddhist literature" by Bhikkhu Bodhi as providing "a vast encyclopedic work which systematizes the practice of the path in a detailed and comprehensive manner". ${ }^{57}$ The text repeatedly returns to the concept of the path. For example:

VII. 91. Those who stand on the path can be understood to have entered on the good way since they possess the right way. And those who stand in fruition can be understood to have entered on the good way with respect to the way that is now past since by means of the right way they have realized what should be realized.

51 Vetter T. 1988. The Ideas and Meditative Practices of Early Buddhism. Leiden: Brill, 7-10.

52 Vetter, Ideas and Meditative Practices of Early Buddhism, 7.

53 Bodhi B. 2000. The Noble Eightfold Path: Way to the End of Suffering. Seattle, WA: BPS Pariyatti Editions, 6 .

54 See, for example, one of the leading texts explaining Mahayana Buddhism, Williams P. 2009. Mahayana Buddhism: The Doctrinal Foundations. Second Edition. London: Routledge, passim esp. the repeated references to the path to Buddhahood; path to full Buddhahood; path to perfect Buddhahood; path to supreme Buddhahood; path to enlightenment; path to nirvana; path to Arhatship; path of preparation; path of the Bodhisattva (including all of ch 9); path of the compassionate Buddha; and the path of insight, amongst others.

Buddhaghosa B. 2010. The Path of Purification: Visuddhimagga. Fourth edition. Nānamoli B (transl.). Colombo, Sri Lanka: Buddhist Publication Society.

56 Buddhaghosa, Path of Purification, xxiii.

57 Bodhi, Noble Eightfold Path, viii. 
VII. 92. Furthermore, the Community has entered on the ... straight way because it has entered on the way avoiding the two extremes and taking the middle course $\ldots{ }^{58}$

In what appears to be the only English-language volume devoted specifically to the concept of the path (mārga) in English, Robert Buswell and Robert Ginello, explain its importance to understanding Buddhism.

We propose that mārga, as the living context within which all Buddhist truth is tacitly but perhaps most effectively defined, creates a commonality of ultimate concerns that reticulates all the various strands of its religious endeavor - its moral values, ritual observances, theoretical doctrines, and contemplative exercises - to form a complex but unified network of practices tending to liberation. [Mārga is] a valuable focus of study, is the way in which it incorporates, underlies, or presupposes everything else in Buddhism, from the simplest act of charity to the most refined meditative experience and the most rigorous philosophical argument. The study of mārga directs attention not to the isolated effects of specific religious practices but to a general pattern of discipline encompassing both the whole life of the individual adherent and the corporate life of the whole Buddhist community. ${ }^{59}$

What is of particular interest for our inquiry here regarding the sharia and other terms signifying "paths" within Islam is the tentative suggestion of Buswell and Ginello that the concept of path - and we add here the metaphor of the path rather than the imposition of legal rules - is the importance of the concept for understanding other religions.

The importance Buddhists assign to systematic discourse about "the path" has general implications that could be valuable in the study of other religions, or of religion generally ... [Religions] are much more than just systems of doctrine, although they do harbor doctrines and often assign them crucially important roles. Religions are also, and perhaps most fundamentally, patterns of action based on axiologies that are as often tacit as they are explicit. As such, religions are embodied in complex ways of life. In some cases these are spelled out in meticulous and explicit detail; in other cases they seem to defy precise and definitive codification; but in no case are they exhausted by the abstract principles or general laws said to [underlie] them. ${ }^{60}$

Although Buswell and Ginello neither make reference to Islam nor suggest that their idea applies to Islam, their point is worth taking seriously. Religion may be understood through different lenses and interpretations of religion and their requirements may evolve over time. Religions themselves, as well as law, take different paths in their development.

58 Buddhaghosa, Path of Purification, 216.

59 Buswell and Gimello, Paths to Liberation, 6.

60 Buswell and Gimello, Paths to Liberation, 4. 


\section{Paths in the Hebrew Bible}

Curiously, outside the Torah itself (the five books of Moses, namely Genesis, Exodus, Leviticus, Numbers and Deuteronomy), the metaphor of a "path" often appears in other books of the Hebrew Bible:

You show me the path of life. ${ }^{61}$

[The Lord is my shepherd who] leads me in right paths. ${ }^{62}$

Your word is a lamp to my feet and a light to my path. ${ }^{63}$

In all your ways acknowledge him, and he will make straight your paths. ${ }^{64}$

But the path of the righteous is like the light of dawn, which shines brighter and brighter until full day. The way of the wicked is like deep darkness. ${ }^{65}$

Let your eyes look directly forward, and your gaze be straight. Keep straight the path of your feet and all your ways will be sure. ${ }^{66}$

Thus says the Lord: Stand at the crossroads, and look, and ask for the ancient paths where the good way lies; and walk in it, and find rest for your souls. ${ }^{67}$

The Hebrew Bible thus can be seen as developing alternate means for explaining God's command: one of following detailed rules laid out with punishments for non-compliance, and a more poetic version that speaks of shepherds and paths.

\section{Paths in the Christian New Testament}

Similar invocations of the tropes of "way" and "path" that are pervasive in the Quran similarly appear in the in the Christian New Testament, particularly in the Synoptic Gospels.

In those days John the Baptist appeared in the wilderness of Judea, proclaiming, "Repent, for the kingdom of heaven has come near." This is the one of whom the prophet Isaiah spoke when he said: "The voice of one crying out in the wilderness: 'Prepare the way [hodos/óoov] of the Lord, make his paths straight."'68

61 Psalms 16:11. All Biblical quotations are derived from the New Revised Standard Edition as appearing in Meeks WA and Bassler JM (eds). 1993. The HarperCollins Study Bible: New Revised Standard Version, with the Apocryphal/Deuterocanonical Books. New York: HarperCollins.

62 Psalms 23:3.

63 Psalms 119:105.

64 Proverbs 3:6.

65 Proverbs 4:18-19.

66 Proverbs 4:25-26.

67 Jeremiah 6:16.

68 Matthew 3:1-3; see also John 1:23. 
Enter through the narrow gate; for the gate is wide and the road [hodos/ ódov] is easy that leads to destruction, and there are many who take it. For the gate is narrow and the road [hodos/ódov] is hard that leads to life, and there are few who find it. ${ }^{69}$

As it is written in the prophet Isaiah, "See, I am sending my messenger ahead of you, who will prepare your way [hodos/ódov]; the voice of one crying out in the wilderness: 'Prepare the way [hodos/ódov] of the Lord,

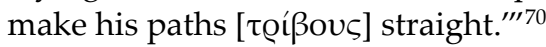

He went into all the region around the Jordan, proclaiming a baptism of repentance for the forgiveness of sins, as it is written in the book of the words of the prophet Isaiah, "The voice of one crying out in the wilderness:

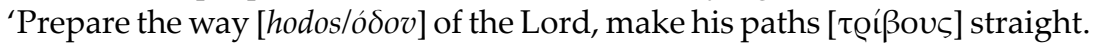
Every valley shall be filled, and every mountain and hill shall be made low, and the crooked shall be made straight."'71

Now the parable is this: The seed is the word of God. The ones on the path [hodos/ódov] are those who have heard; then the devil comes and takes away the word from their hearts, so that they may not believe and be saved. ${ }^{72}$

Thomas said to him, "Lord, we do not know where you are going. How can we know the way [hodos/ódov]?" Jesus said to him, "I am the way [hodos/ ó $\delta$ ov], and the truth, and the life."73

He [a Jew named Apollo] was an eloquent man, well-versed in the scriptures. He had been instructed in the Way of the Lord [hodos/ódov]; and he spoke with burning enthusiasm and taught accurately the things concerning Jesus. ${ }^{74}$

They have left the straight road [hodos/ódov] and have gone astray. ${ }^{75}$

By considering the examples above from Daoism, Buddhism, and the Bible, we can see that it is entirely consistent with several religious traditions to explain the proper or preferred conduct for human beings by the metaphor of paths, rather than laws and detailed obligations replete with punishment for non-compliance. This observation does not mean however, that the Quran - or the Hebrew Bible before it - omits discussion of law.

69 Matthew 7:13-14.

70 Mark 1:2-3; see also Matthew 1:2-3; Luke 7:27.

71 Luke 3:3-5.

72 Luke 8:11-12.

73 John 14:5-6.

74 Acts 18:24-25.

752 Peter 2:15. 


\section{CONCLUSION}

Many today use the Quranic term "sharia" as the term of art that encompasses Islamic law and the divine commands given to human beings. Sharia is thus used to evoke religious obligations, laws, commandments, edicts, decrees, judgments and rules, as well as to articulate the forms of punishment and the penalties for the violation of divine laws. It is almost as if sharia should be understood as a vast and comprehensive legal code to regulate human behaviour with precision. And the ultimate source for the sharia, both in substance and in the word itself, is Quranic. Yet the Quran itself does not speak of laws per se - kanun in Arabic - but uses a multiplicity of synonyms for "path" of which sharia is only one, and which itself is used only once. The vast majority of the Quranic text is not legal, and it certainly is not a comprehensive legal code. The vastness of what is characterised as sharia today was articulated by human beings long after God completed the Quranic revelation and articulated a Quranic path. Rather than offering human beings a systematic legal code replete with comprehensive punishments, the text itself repeatedly evokes an all-merciful and all-forgiving God who gives general guidance on paths that human beings should follow - sirat, sabil, tarik, minhaj and sharia - whereby they might flourish in this life and the next. Perhaps Abdel Razek's message was well taken: Islam is a religion and not a state. 